working capital is earned by a more modest entry into exporting. Conversely, it is entirely possible for any manufacturer, adequately financed for domestic trade, to plan correctly for ultimate world-wide trade and to proceed step by step, directly toward his goal.

\title{
The Probable Future Development of Grain Trade of the United States
}

\author{
By Julius H. Barnes \\ Barnes-Ames Company, Duluth
}

$\mathrm{W}^{\mathrm{s}}$ AR'S influence is clearly shown in a study of the food supply of Europe during war-years. The change wrought in sources of overseas supply rises strikingly above all other phenomena and centers in the expansion of food production in America and the clear deflection of ordinary ocean trade currents in the products of the farm. For example, there is in a study of crop production, marketing and movement, as influenced by the necessities of warring countries, a clear indication that price inducement is the governing factor most apparent in America's farm yields.

Prior to the war there was a general acceptance that in America there were two distinct trends in grain production:

1. The elimination of our export grain surplus by the growing necessities of a home population.

2. The reduction in total grain yields by the replacement of diversified farming.

We are now able to see, by the actual response of American farms to the price inducement which war's higher levels created, that both the area of grain production and the yield per acre were possible of material enlargement. This trend is most clearly shown by a grouping of the years' production, for the purpose of ready comparison.

The four years prior to the world war recorded an average grain production of the United States, as follows:

Bread grains (Wheat and Rye)

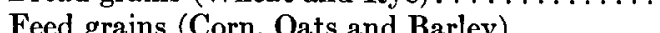

Total grain production ( 5 chief crops)

The five war years averaged in grain production as follows:

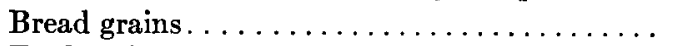

Feed grains

8.6 bushels per capita

Total grain production ( 5 chief crops).
7.8 bushels per capita $40.32 "$ " "

$47.4 \quad \cdots \infty \cdots$

With ocean commerce freed of the submarine menace, but production still under the influence of war grain prices, the crop of 1919 recorded a yield of:

Bread grains

Feed grains

Total grain production ( 5 chief crops)
9.77 bushels per capita

40.93 
The crop of the 1920 harvest, of which the final figures are just available, yielded:

Bread grains.

Feed grains.

Total grain production ( 5 chief crops)
8.01 bushels per capita 46.25

54.26
Studying these yields, it is apparent that, even with the minor fluctuations which sectional and seasonal crop deterioration produced, the trend was steadily toward enlarged grain production. If we seek for a reason for the larger acreage sown and the larger aggregate yields, in the face of greater production difficulties on the farm, especially as to labor supply, we find the answer in the price inducement.

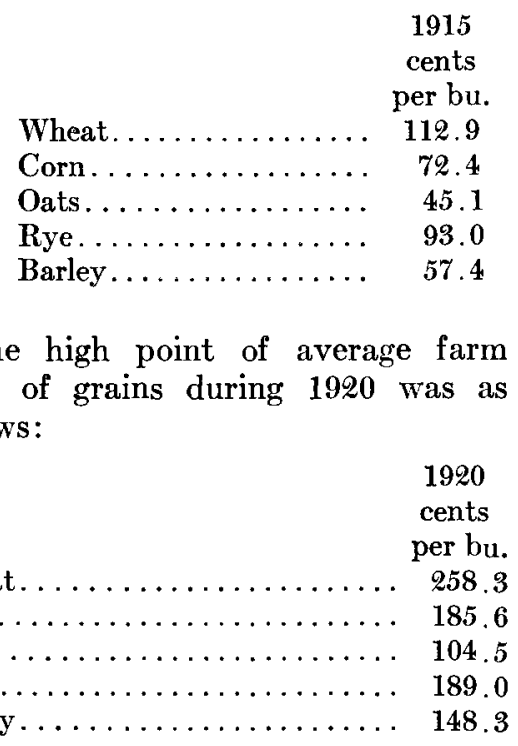

Here is clearly disclosed the crop expansion following a steadily advancing price level which represents production stimulus to the grower. It is possible to verify, besides, that the increase in grain crop production was paralleled by a similar increase in yield in other farm products; and that the price stimulus came primarily from overseas is told most
An analysis of the farm price for grain shows the following average for the four pre-war years:

Wheat. . . . . . 85.5 cents per bushel Corn.......... 65.4 " " "

Oats.........

Rye............ 71.9 " “ "

Barley......... 62.8 " " "

An analysis of the average farm price of grain for the five years 1915 to 1919 shows the following:

\begin{tabular}{|c|c|c|c|}
\hline 1916 & 1917 & 1918 & 1919 \\
\hline cents & cents & cents & cents \\
\hline $\begin{array}{c}\text { per bu. } \\
117.3\end{array}$ & $\begin{array}{c}\text { per bu. } \\
201.1\end{array}$ & $\begin{array}{l}\text { per bu. } \\
203.7\end{array}$ & $\begin{array}{l}\text { per bu. } \\
214.8\end{array}$ \\
\hline 75.7 & 141.4 & 150.4 & 155.7 \\
\hline 43.6 & 63.4 & 76.8 & 69.7 \\
\hline 93.2 & 156 . & 178.4 & 141.3 \\
\hline 66 & 107.4 & 124.2 & 105.4 \\
\hline
\end{tabular}

clearly in the total food exports of the United States, as follows:

Exports of All Foodstuffs from the United States

$\begin{array}{cc}\text { Year } & \begin{array}{c}\text { Tons } \\ 1912-13 \ldots \ldots \ldots \ldots\end{array} \\ 1913-14 \ldots \ldots \ldots \ldots & \mathbf{7 , 9 0 0 , 0 0 0} \\ 1914-15 \ldots \ldots \ldots \ldots \ldots & \mathbf{1 5 , 9 0 0 , 0 0 0} \\ 1915-16 \ldots \ldots \ldots \ldots \ldots & 13,500,000 \\ 1916-17 \ldots \ldots \ldots \ldots \ldots & 12,600,000 \\ 1917-18 \ldots \ldots \ldots \ldots \ldots & 10,000,000 \\ 1918-19 \ldots \ldots \ldots \ldots \ldots & 17,000,000 \\ 1919-20 \ldots \ldots \ldots \ldots & 11,700,000\end{array}$

It is possible, thus, to trace the production and export expansion following the inducement of a higher oversea price, and also to see, in the shrinkage of overseas outlet following the end of war anxiety and war finance abroad, the beginning of deflation of price attraction on the American farm, which culminated in the Fall of 1920 in 
a considerable collapse of farm product prices.

If, then, we recognize the ready response which the American farm can make to prospective profits by price stimulation, it would be interesting to reach a conclusion, also, as to whether even under the stimulus of war's inflated prices we had reached our capacity production. A comparison of the pre-war average production per acre of eighteen European countries last available indicates an average wheat yield per acre exceeding that of the United States average by fifty per cent. In spite of the fact that large areas of our country are more exposed to seasonal crop deterioration and resultant disappointing yields than are the same areas in Europe, it seems from a study of the crop expansion thus recorded that the spread between the two comparisons of acre yields can be narrowed by increasing American crop production whenever the American price return at the farm warrants the investment in fertilizers and intensive cultivation which Europe has generally practiced. That intensive cultivation and expense in soil stimulation will follow a continued price return which makes such intensive production profitable, and no sooner.

Since, then, it is the final farm return which will determine the expansion or contraction of aggregate grain yields in the United States, it is important to see what natural conditions may facilitate or retard the reflection to the farm of the largest possible percentage of the consumer price. The United States has prospered in the past as a grain-raising country, producing a surplus for the European consuming markets, though in competition with the cheap-labor production of Russia, India and Argentina. Its chief South American competitor possesses a con- siderable natural advantage in the proximity of its grain areas to its seaports. It is calculated that the average rail haul from the Argentine farm to some one of its seaports will not exceed 150 miles.

In the United States a large percentage of our grain area necessitates a rail haul of 500 to 1,500 miles. The American farm has been favored heretofore with cheap rail transportation and, more than that, by the extraordinary economy of the thousand miles of deep water Great Lakes navigation. On these Great Lakes the transportation of bulk grain is the lowest per ton mile in the world, and not only has the grain country benefited in the actual transportation of grain by this water route reaching into the heart of America, but the influence of its cheap carriage rates has reflected into competitive rail haulage as well.

Railroad rates were long framed with especial consideration on grain, and additional consideration on export grain. This condition has changed. There has been one rail advance after another, together with an equalization of rail and export rates, until it may be stated that in respect to certain grains, and for certain rail routes, the rail transportation charge has doubled within the past five years. This charge was not an undue burden during the recent years when Europe's needs and war's inflation of values supplied a ready market at high prices for American production. Today, when the transportation charge per bushel from the Nebraska and Iowa farm to the seaport is more than the value per bushel of corn at the farm, it becomes a serious impediment to the continuation of America's grain export supremacy. It is apparent that, even with Russia's continued elimination from the overseas grain balance-sheet, there are, in the immediate future, 
days of sharp competition for markets in Europe which will distinctly reduce the price inducement of the past few years. Grain production in the United States will probably show the effect of this unfavorable development.

American resourcefulness and American methods of using mechanical devices rather than human labor, may overcome in large part the handicap of high cost production following an advanced standard of farm living, and the disadvantage of necessary long hauls to the ocean, but it is none too early to study every economy along the line of translation, in the interest of preserving the farm price as far as possible.

If, for instance, the international engineers now preparing a report on the feasibility and cost of the St. Lawrence Waterway should indicate not excessive costs in the introduction of the ocean carrier to the inland lake ports of Duluth, Chicago and Milwaukee, serving the inland grain empire, this one factor of economy itself might be decisive in maintaining the price stimulation on our western farms.

It would serve also to attract to European markets the surplus of western Canada, which, without cheap transportation facilities to Europe, must press along the American border into our own markets as well, and with the advantage of low-cost production which a relatively virgin soil insures. It is significant, for instance, that in this present crop-year (Russia being eliminated), the United States and Canada are supplying eighty per cent of the overseas requirements of bread grains. If these countries find competition with grain exporting coun- tries forces them to enter the export market at a price leaving only unprofitable farm returns, because of large transportation costs, then in those American areas in which both American crops compete, there might be such pressure for home markets that the agricultural industry in those districts would be wrecked.

If America is to achieve a supremacy in the export of industrial production, competing there as also it must with the cheaper wage costs which obtain in a lower standard of living, it not only must again use the economies of mechanical and large-scale production, but it must also supply our workers with a relatively cheap food supply. The ideal of that food supply would be a domestic price lower by its export relation than the food price level of other industrial competitors, yet high enough to make a fair return to the American grower. The position of that grower in respect to his price return must be developed and secured by all the study and resourcefulness of which America is capable and for which it should be typical.

It is clear that the potential crop production exists in America. It is clear that it responds readily to price inducement. It would be an economic blunder not to try to maintain that crop production by preservation in America of a price inducement following farm profits. Economies into the consumer market secured by cheaper transportation, and simplification of trade methods and reduction of trade tolls, will aid in maintaining grain production in the United States. The potentiality is clearly present beyond the needs of home consumption alone. 